\title{
Slipware from Tykocin Castle (Poland) from the 16th-18th Century
}

\author{
Magdalena Bis ${ }^{a}$
}

\begin{abstract}
The main goal of this article is to analyse post-medieval slipware found during archaeological excavations in Tykocin Castle and to describe its distinguishing features: decorative characteristics and forms. Further considerations are aimed at reconstructing the functions of the Tykocin slipware vessels in the castle household throughout the 16th to 18th centuries and attempting to determine their provenance. The analysis is preceded by the list of terminological problems pertaining to this pottery group in the Polish literature as well as elementary information on its production centres in Poland against the European background.
\end{abstract}

KEYWORDS: slipware, slip-decorated earthenware, lead-glazed redware, post-medieval pottery, semi-majolica, Tykocin Castle

\section{INTRODUCTION}

Pottery studies constitute an integral and constant aspect of archaeological research, since pottery is one of the most elementary archaeological sources, usually well-preserved and often found in large quantities, shedding light on everyday life in the past. Generally this holds true for the post-medieval period and the developments in pottery-making on the European continent that occurred throughout the I6th-I8th centuries, which were predominantly manifested in the introduction of innovations unknown in the late Middle Ages: an extended assortment of forms and the differentiation of types of the produced vessels. This process mostly entailed the emergence and the gradual spread of luxury ceramics (such as majolica, faience, or porcelain) and more ordinary items (including glazed-ware, whiteware, or slipware) that complemented the "traditional" pottery (redware and greyware). These novelties also included personal and specialist utensils (such as plates, cups, kettles, or vases).

This diversity is also reflected in the assemblage obtained from the castle site in Tykocin, situated in Podlachia, north-eastern Poland. It comprises finds collected

a Institute of Archaeology and Ethnology, Polish Academy of Sciences, Al. Solidarności I05, 00-I40 Warsaw (Poland); e-mail: magdabis@wp.pl; https://orcid.org/oooo-ooo2-oro8-7625 
so $\mid$ Magdalena Bis

during archaeological excavations conducted there in the years 196I-1963 and 19992007 (for more information on the scope and results of these works, see Bis and Bis 2006; 20I5a). Pottery clearly dominates the rich collection of artefacts discovered at that site, amounting to $65,87 \mathrm{I}$ pieces or $72 \%$ of the total number of artefacts. The majority are vessels of various types $-50,469$ fragments, i.e., $76.6 \%$ of the ceramics and $55 \%$ of the whole assemblage from the site (see Bis 2015: 96-97, Table 2). Only a few of them - 137 fragments, merely $0.2 \%$ of total pottery - comprise sherds of the slipware discussed in this article ( 75 vessels in total). They are made of ferrous clays (redware), fired in an oxidising atmosphere, and decorated with painted ornaments of different complexity and techniques. For this purpose a slip (diluted clay) was used, creating an underlay for ornamentation and serving as a paint for the patterns. The decorated surface was covered with lead glaze. These vessels were used by the residents of Tykocin Castle in the modern era and after destruction were deposited at the site in cultural layers dated to the period between the second half of the i6th and second half of the i8th centuries.

The aim of this article is to draw attention to this small but distinctive pottery group and contribute to the Polish archaeological discourse on its production in what is contemporary Poland as well as the related terminological questions in the context of the European background. The main part of the text offers a characterisation of the finds from Tykocin Castle in regard to their morphology, function, and decoration, to the extent allowed by their state of preservation. These observations then serve as a basis for a discussion on the functions of these vessels in Tykocin Castle throughout the I6th-18th centuries. An attempt has also been made to determine their provenance.

\section{TERMINOLOGY AND RECENT FINDS}

Foreign literature uses several related terms connected to the pottery discussed here. In the English nomenclature, they are usually referred to as slip-decorated lead-glazed earthenware, redware with slip decoration, or, simply, as slipware, whereas the ornamentation itself is called slip trailing, slip-trailed decoration, or slipped decoration. German works tend to use Malhornware or bleiglasierte Irdenware (cf., Stephan 1987; Gaimster 2006). These terms are commonly accepted and used by foreign scholars in regard to this type of pottery. The above state of affairs, just as the whole development in research on these matters in Europe, is largely a consequence of the seminal study by Hans-Georg Stephan, published 34 years ago and monumental in its chronologicalgeographical scope (Stephan 1987; this work also lists older literature). Stephan's legacy has been continued (for more on the studies on slipware in Europe, as well as general remarks on subsequent publications and discoveries, see e.g., Stephan I99I; Gaimster I99I; 2009: 534-535). 
Although in foreign publications these issues are settled, in Polish archaeological papers there is still a lack of consistency in the naming of the pottery examined here. Several terms are used, ${ }^{1}$ often interchangeably. The most long-standing and commonly used and established among them are: semi-majolica (Polish: pótmajolika; in studies over the past decade, e.g., Mackiewicz 20I2: I52-I54; Miazga et al., 2012: 49; Garas and Karwowska 2013: 238-24O; Poklewska-Koziełł 20I3: II3-II7, tabl. I2-I4; Kruppé and Milewska 20I4: 86-87; Affelski and Trzeciecki 20I6: 173-174; Pankiewicz and Rodak 20I6: 35I-352; Trzeciecki 20I6: 4I-42, I29-I30; 20I7: I7I-I83; Wojenka 2016: 232-240; Rodak 2017: 162-163; Włoszek 20I7: I05-106; Paterczyk 2018: 82-87; Meyza 2019: 69; Niedźwiadek 2019: 249; Zamelska-Monczak 2020: 155) and pseudo-majolica (Polish: pseudomajolika; in more recent works, e.g., Garas and Trzciński 20IO: 27-28; Oniszczuk 20I3a: 26; Pawlata 2013: 136; Starski 2013: 167-I70; 20I5: II9; Dryja 20I4: I32; Gajewska and Kruppé 20I7: 127-I29; Lis 20I7: 347-350; Trąbska et al., 2019).

Other names have been proposed by researchers, but are far less popular. These include: lead-glazed earthenware with underglaze decoration (Polish: ceramika zdobiona podszkliwnie; mostly in Meyza 1991; 1993; 2017a; also Marcinkowski 2009; 2019: 93-95), and engobed earthenware with underglaze decoration (angobowana zdobiona podszkliwnie, as in Pytlak 2013: 69-7I), painted red ware (Polish: ceglasta malowana), white-washed and glazed redware (Polish: ceglasta szkliwiona na angobie), slipped earthenware (Polish: naczynia ceglaste malowane na angobie), (see Lechowicz 20I2: II8-II9; Dąbal 20I5: 232-236; 20I8: 316-3I7; Dąbal and Szczepanowska 2018: I8I, I85; Wołyńska 2020: IIO-II3), as well as decorated with a piping bag (zdobione rożkiem, see Mackiewicz 20I2: 13I), redware painted with a piping bag and glazed (Polish: ceglaste malowane rożkiem i szkliwione, e.g., Majewski 2017:95), as well as red ware engraved, painted with a piping bag cone and glazed (Polish: ceglaste szkliwione rytowane $i$ malowane rożkiem, e.g., Kwiatkowski and Majewski 2016: 154, I8I-183, Fig. 4-6; Majewski and Wojciechowska 2019: 79-82), or polychrome pottery (ceramika polichromowana, see Szwed 2004: 342-343). In some cases, the name mezzamajolica is also used (mezzamajolika, in newer works, e.g., Garas and Trzciński 20I0: 27; Mackiewicz 20I2: 152; Poklewska-Koziełł 2013: II3; Pankiewicz and Rodak 2016: 35I; Paterczyk 2018: 82).

The majority of these terms are imprecise, as they were arbitrarily chosen to refer to several groups of pottery differing in terms of manufacturing technique but sharing similar painted decorations under lead glaze (Meyza I99I: II8-II9; 1997: I25-I27; see also Marcinkowski 2009; 20II: 15-16). Although they are still subject to debate, some of these terms have already become established in the Polish literature and are used to

1 Due to the short form of the article, my aim is only to indicate the main terms used in the Polish literature with regard to this type of pottery. I will not analyze here the origins of these concepts, nor discuss publications in which they were used. 
s2 $\mid$ Magdalena Bis

generally identify this type of vessels. These took place even though the prefixes used, such as "pseudo-" or "semi-", are value-laden and depreciate pottery called this way by comparing it to other types of presumably better quality - majolica or faïence - or suggesting that they are their imitations or forgeries. On the other hand, "lead-glazed earthenware with under glaze decoration" may just as well refer to vessels decorated this way but of a different type - the so-called Pomeranian faïence.

It seems that the most adequate term in the Polish language would an expression reflecting two primary features of these artefacts, i.e., the raw material and ornamentation - Polish: ceramika ceglasta angobowana szkliwiona [lead-glazed redware with slip decoration]. In my opinion, it is worth considering using the simplest, common English term - slipware. Both of these definitions (slipware and ceramika ceglasta angobowana szkliwiona) are broad enough to include slip-decorated vessels, where the slip differs in terms of methods of application and consistency. These are earthenware vessels with slip of thicker consistencies, which could be trailed, poured, or squeezed, or of thinner consistencies, which could be applied with a brush, a rag, or by hand. A design could also be cut through the overlying slip, exposing the contrasting colour of the clay body beneath (sgraffito decoration; see MPRG 1998: chapter I2.5-I2.6; Orton and Hughes 2013: 86-88). I use this extensive meaning as the definition of the group of vessels discussed.

The unfading scholarly interest in this pottery is a European trend (the newer foreign publications are Amato et al., 2009; Funke and Leiber 20I2; Gawronski 20I2; Kröll 20I2; Witte 20I4; 20I6; Demuth 20I5; Bikić 20I7; Gajić-Kvaščeva et al., 20I8; Blažková 2019; Giorgio 2019; Heege 2019a; 2019b; Matějková 2019; Ose 2019: 72-74, II7-II9; the works list further literature). On the one hand, it is related to the ongoing development of historical archaeology and studies of post-medieval pottery, including the expanding knowledge of slipware. On the other, it reflects the considerable frequency of these artefacts and their spread across the continent throughout the 16th-18th centuries, as well as European developments in decorated pottery production inspired by the Renaissance.

As indicated by the above-mentioned examples, the last decade has seen an increase in the known source base related to this pottery in Poland as well as publications referring to it. Such vessels have been found in various regions at sites containing post-medieval archaeological material. The dating of the Polish finds falls into the period between the second half of the i6th century and the i8th century. They match the European manufacturing standards at that time, both in terms of ceramic forms and their decoration techniques.

\section{PRODUCTION CENTRES}

Some of the most important regions in Europe where slipware was manufactured were located in today's Germany, of which the best-known are Weserware and Werraware. 
The period when these vessels were produced in larger quantity extended over several decades (I580-1620/I630 and I568-1620, respectively) and ceased when the Thirty Years' War broke out. The basic assortment consisted of tableware supplemented with kitchenware. Weserware was manufactured between the rivers Weser and Leine, in Altenhagen, Brüninghausen, Dörpe, Höxter, and Völksen. The primary distinguishing features of these vessels were simple colour ornamentation, mostly geometric and floral motifs (including zigzag lines) on a bright overlay (thanks to the use of white slip), and flat bases. Werraware was manufactured in Hesse, in the following production centres: Eschwege, Grossalmerode, Hannoversch Münden, Heiligenstadt, Treffurt, Wanfried, and Witzenhausen. What distinguished these vessels was that many specimens had painted production dates and ornaments made predominantly in the sgraffito technique, usually bright figural motifs against a dark underlay (e.g., Stephan 1987: 85-IIO, 274-280; Gaimster 1988; 2006; Bartels 1999; Demuth 200I).

Both of the aforementioned groups were numerous and widely distributed (Stephan 1987: 85-IIO, 274-280; the work lists further literature). They also reached the coast of the Baltic Sea (including Poland), as evidenced by archaeological finds and their recent publications (e.g., Demuth 200I; 2015; Russow 2006; Niukkanen 2007; Dąbal 20I3; Oniszczuk 2013a; 2013b; Russow and Haak 2018; Ose 2019; Linaa 2020). Weserware and Werraware seem to be foreign slipware the most often identified in Polish post-medieval ceramic assemblages (e.g., Szwed 2004: 343; Dąbal 2013; 2015: 232-233; Oniszczuk 2013b: 89-90, Nos 377-391; Kwiatkowski and Majewski 2016: 154).

Another significant continental region where slipware was manufactured was the Lower Rhineland, especially Coppengrave, Duingen, Duisburg, Hohenbuchen, and Wesel (e.g., Gaimster 1988; 2006). However, many other manufacturing sites in central and northern Europe have been identified (see Stephan 1987), for instance Lüneburg, Rostock, or Husum in northern Germany (e.g., Schäfer 2007; Kröll 20I2; Witte 2014), Beauvais, Pas-de-Calais, Arras, or Douai in northern France (e.g., Gaimster 199I), Schüpbach in Switzerland (e.g., Heege 2019a: 96), centres in southern Denmark (e.g., Witte 20I6), Stockholm in Sweden (e.g., Johansson 2007), as well as Beroun and Levín in Czechia (e.g., Blažková 2019; Matějková 2019).

In the territory of modern-day Poland, the considerable amounts of known slipware finds contrast with the scarcity of identified and published post-medieval potterymaking centres or at least potential production sites. According to my findings so far, there were at least about a dozen such sites, located in different parts of Poland (due to the limited size of this paper, they are only listed below). In this regard, the archaeological perspective remains clearly distinct from the findings made by ethnographers (cf., Fryś-Pietraszkowa 1970: 68-69, il. 259; this author included 59 pótmajolika production centres that operated in the post-medieval period and are inactive nowadays).

The production centre that initiated Polish studies of this type of pottery in Poland, and which remains the best-researched so far, is situated in Miechocin, nowadays 
54 Magdalena Bis

a suburb of Tarnobrzeg in Lesser Poland (current Podkarpackie Voivodeship; SzarekWaszkowska 1967; Szetela 1969a; Szetela 1969b; Szetela-Zauchowa 1994; see also the leaflet by Handerek 2006). Excavation work at this site uncovered remains of I2 workshops, along with finished products and post-production waste. These operated in different periods between the late i6th century and the end of the i8th century, and the heyday of that production centre is dated to the first half of the i7th century. The goods manufactured there were divided into several groups according to their chronology and ornamentation.

Other potential production sites in the region were at Rzeszów, Łańcut, and Jarosław, based on slipware finds and historical records concerning pottery workshops functioning there in the 16 th and 17 th centuries. However, no material remains of workshops manufacturing slipware have been discovered so far. The collected potsherds represented an assortment similar to that from Miechocin, except for slight differences in decorative motifs and colour schemes (cf., Kotula 1953; 1956; Supryn 1975; Czopek and Lubelczyk 1993: 25-27).

One more place where slipware was manufactured in the 16th-18th centuries may have been Lublin (currently in the Lublin Voivodeship) or its environs. The abundance of finds and their significant representation in pottery assemblages from different local sites (e.g., Niedźwiadek 2019: 249), especially in manor houses (often above 50\%), seem to support the above assumption. Despite such a high frequency, no slipwaremanufacturing workshops have been discovered so far (personal communication with Rafał Niedźwiadek, July I9 202I).

Nevertheless, excavations have provided undisputed physical evidence for slipware production in Cracow (currently in the Lesser Poland Voivodeship) in the second half of the 16th century (Dryja 20I4: 13I-I32), as remains of a workshop were unearthed in the suburb of Garbary, in II Loretańska Street. These vessels were fired in kiln III, along with a wide repertoire of other products (stove tiles as well as ceramic details and building materials).

Another workshop that probably manufactured redware with slip-trailed decoration alongside stove tiles, was discovered in Greater Poland, in Garczary, a suburb of Śmigiel (Wyrwińska and Wyrwiński 2005). At this site, archaeologists recorded remains of two kilns that operated in the second half of the I7th century. Glazed redware vessels with slip decoration were deposited mostly around the kilns and in their backfills and were interpreted as unused specimens or production waste (Wyrwińska and Wyrwiński 2005: 304-305, 307, Fig. 8).

It is sometimes suggested in publications that a workshop or a complex of workshops manufacturing similar post-medieval pottery existed also on Wzgórze św. Wojciecha (St. Adalbert Hill) in Poznań (Greater Poland Voivodeship; e.g., Poklewska-Koziełł 2013: II7; Paterczyk 20I8: 87). The workshop that was recorded at that site produced panel tiles, among other things, which were dated to about the middle of the I6th 
century, as well as some unspecified vessels (Łaszkiewicz 1993). Until these finds are fully published, however, this information remains unconfirmed.

The slipware excavated in Brzeg, Silesia (current Opole Voivodeship), at a site located in IO-I2 Dzierżonia Street, has been considered to be of local origin. These finds were semi-majolica plates with redware and cream-white bodies, dated to the late I6th and I7th centuries, and constituted only a small percentage of the ceramic finds. The operation of a dynamic post-medieval pottery production centre in the town is attested by other archaeological sources and written records (Rodak 20I7: I49-166).

Vessels of this type were also manufactured in Mazovia, in Warsaw, in one of the two pottery kilns (upper one, marked as no. I) located within the former moat of the Old Town. This facility was interpreted as the workshop of Master Jan Rosołowicz, active in the late I7th century (Świechowska and Dukwicz 1955: 154-I57, tab. I5; see also Meyza 20I7b: 189-190). Its production focused on redware vessels, stove tiles and clay tobacco pipe bowls (Polish: lulki). In a recent verification of the excavation results, the dating of the finds was changed to the first half of the I8th century (Meyza 20I7b: 196).

Two more slipware production sites were found in the Zachodniopomorskie Voivodeship. Such manufacturing activity in Myślibórz (Soldin) is evidenced by a pottery kiln preserved with its entire load and numerous pits filled with potsherds and fragmented stove tiles (Kałagate and Kościukiewicz 2004; Szymczyk 20II; Majewski 2019: 208), located near the town walls, behind the Pyrzycka Gate. The workshop functioned between the late i6th and early I8th centuries. The vessels found there stand out through their rich decoration (including the use of the chattering technique) and diversity of forms.

Remains of two presumed pottery workshops that operated after the late I6th century were discovered in Recz (Reetz/Neumark), in the housing blocks adjoining the town walls. Admittedly, no traces of manufacturing facilities have been found there, but the local production is evidenced by pottery wasters - potsherds and fragmented stove tiles, as well as unfinished and defective products (Majewski 20IO; 20I6: 8I-84; 2019: 208-209).

Based on the above-mentioned examples, we may assume that the slipware characterised by its average quality and schematic decorative motifs may have been manufactured in many other pottery production centres and workshops as a part of a wider range of pottery, along with plain earthenware.

\section{MATERIALS AND METHODS}

The vessels discussed in this study were discovered in Tykocin Castle. This is a fortified structure situated opposite the town of Tykocin, on an elevation in the flood plain of the Narew River. It existed in its elementary form - a quadrangular brick-built 
s6 $\mid$ Magdalena Bis

building - between the third quarter of the I6th century and the second half of the i8th century. The castle, together with bastion-type fortifications, was built on the orders of King Sigismund II Augustus. ${ }^{2}$ Probably before 1630, when Krzysztof Wiesiołowski served as the castle's starost, the building and its interiors were modernised, with the surrounding fortifications transformed into a large bastion-type stronghold. A siege in 1657, during the Polish-Swedish war, brought severe damage to two of the four wings of the castle. However, the remaining part of the complex was still in use, at least for the next several decades. The castle belonged to the king until I66I and afterwards was taken over by private owners: Hetman Stephan Czarniecki followed by the Branicki family of the "Gryf" coat of arms (to I77I). The fate of the building was sealed when a fire consumed it in I734, along with the furnishings. After this disastrous event, no further attempts at reconstruction were made and finally (in the late 1760s) what remained of the castle was dismantled. Thus, its regular functioning was decisively terminated. Throughout the igth and early 2oth centuries, the relics of the building continued to deteriorate (cf., Bis and Bis 2006; 2015b).

The functions of the building changed throughout the two centuries of its existence depending on its proprietary situation and geo-political conditions. Since the beginning, it was meant to act as an important defensive point in this part of the Polish-Lithuanian Commonwealth, a garrison, and an arsenal. In addition, it safeguarded the private belongings of the last of the dynasty of Jagiellons (until I573). Even at the beginning of the I8th century, it was still an important strategic point occupied by various armies during the military conflicts taking place in the Podlachia region since the mid-I7th century. It became the seat of the Tykocin starosts (after I572) and burgraves (castle administrators), a workplace for its numerous staff (including craftsmen of various trades and local villagers tasked with different services), and a place for judicial activities. The complex was also important for the local economy, as it comprised a building for economic functions, a granary, a brewery, an inn, a coach house, stables, and ponds. The castle was visited by several Polish elective monarchs and their courts: Stephen Báthory, Sigismund III Vasa, Ladislaus IV Vasa, Augustus II the Strong, Stanislaus I Leszczyński. It also served as a temporary residence for its owners - the Branicki family - and hosted important national events as well as local gatherings. In the course of the two centuries of its functioning (from the 1550 os to the end of the 1760s), the number of people residing and eating at the castle fluctuated and is currently difficult to determine with precision. The same is true for their social or material standing and the related differences in consumption patterns and demands (cf., Bis forthcoming).

2 Here, I ignore the earlier stage - from the late 15 th to the early i6th century - when the castle functioned as a wooden structure belonging to the Lithuanian family of the Gasztołds. No slipware was dated to this period. 
The I960s, when the castle was to be transformed into a permanent ruin, saw the first archaeological excavations and architectural studies at the site, conducted by Jerzy Kruppé. Towards the 1990s, further archaeological exploration was undertaken and continued until 2007 to enable planned reconstruction of the castle. The latter earthenworks were managed by Magdalena Bis and Wojciech Bis (for more details, e.g., about discoveries, stratigraphy, objects, and other finds, see Bis and Bis 2006; Bis 2015). This research encompassed the remains of castle buildings - their interior and the castle's direct vicinity - up to the line of the bastion fortifications. They focused on the western, south-western, and north-western parts of the complex (cf., Bis 20I5: 80, Fig. 30).

All finds discussed in this paper were discovered during the above-mentioned excavations (in total, 137 slipware sherds coming from 75 vessels). Most finds (44 vessels, i.e., almost 59\%) were found during the excavations carried out in the years 200I-2007, whereas the rest (3I specimens, i.e., $4 \mathrm{I} \%$ of the total vessels) in the course of work conducted between 196I and 1963 (Fig. I). It is noteworthy, because the earlier finds are predominantly loose, as they have been obtained from architectural trial trenches

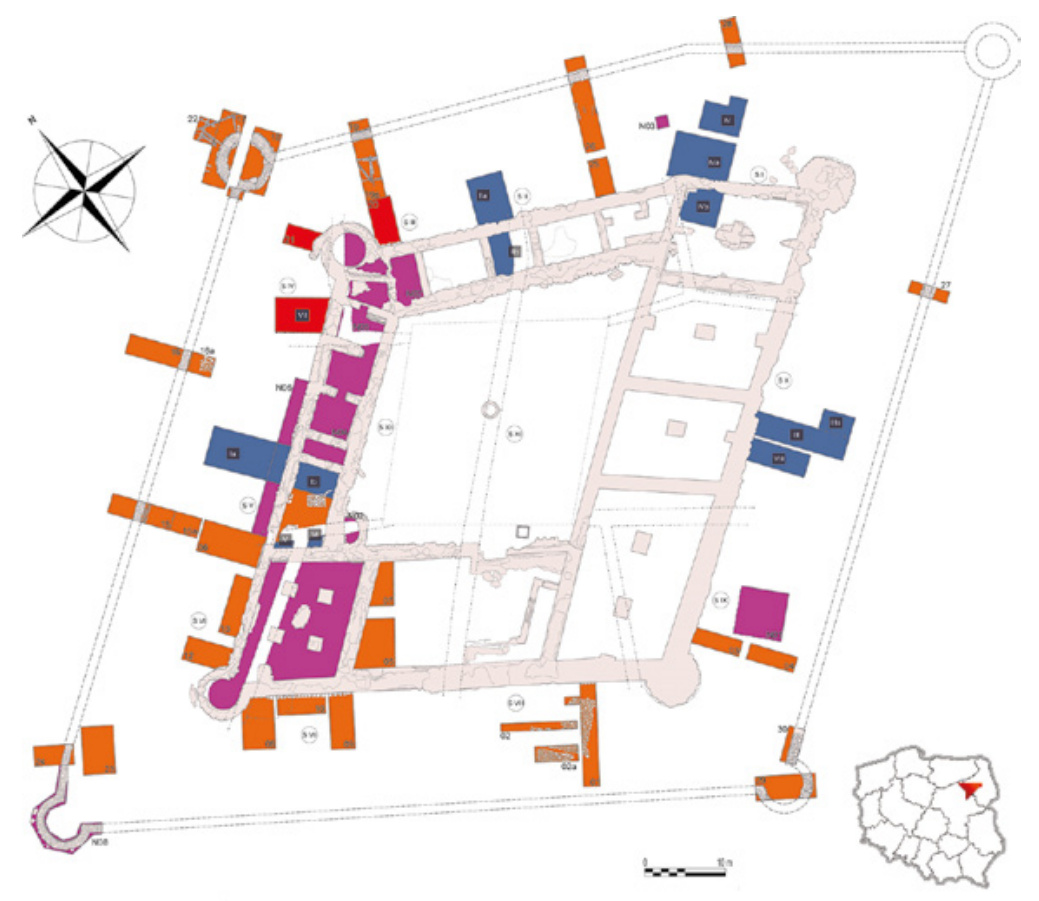

Fig. 1. Outline of the foundations of Tykocin Castle with location of trenches (orange and blue colours) and watching briefs (purple colour) from the years 1961-1963 and 2001-2007. The trenches with the biggest amount of slipware vessels are shown in red. Prepared by W. Bis. 
or regular excavations but with stratigraphic contexts that are currently difficult to reconstruct. Some of the vessels from the methodical excavations at the beginning of the 2Ist century were obtained from recently-mixed layers - transposed within the complex or forming backfills of the earlier trenches. In these cases (41\% of the slipware in total), it was assumed that they came from the time of the brick-built castle, i.e., the second half of the 16 th to the second half of the i8th century. Therefore, they have no bearing for the chronological diversity of the assemblage. The majority of the remaining, and well-dated, artefacts come from the cultural layers formed in the I7th and I8th century.

Their frequency in different parts of the complex was uneven. Slightly more vessels (I6) were discovered near the northern bastille (trenches nos. VII, 20 and 2I). It was an area where broken items or elements of castle equipment (e.g., stove-tiles) were discarded during cleaning works in different periods, e.g., after the Swedish Deluge (1655-1660).

The drawback of many of the discussed finds is their poor state of preservation heavy fragmentation, the small size of the sherds, and surfaces damaged due to postdepositional factors. In effect, assessing their morphology and differences in particular elements is problematic, just as is inferring their decoration, including the types of depictions, their distribution and layout, and connection to the vessel tectonics. Only three vessels were completely or largely reconstructed: one plate and two bowls. The majority of the finds are parts of rims (3I), bases (19), bodies (24), and a single handle.

They represent two main categories of vessel forms - closed wares and open wares (cf., MPRG 1998: chapter I.3.3). They were: plates, bowls, pots, mugs, jugs, and a lid (Table I).

Table 1. Types of slipware vessels from Tykocin Castle, the 16th-18th c.

\begin{tabular}{|l|c|c|c|c|}
\hline \multicolumn{1}{|c|}{ Vessel form } & $\begin{array}{c}\text { Sherd count } \\
\text { (SC) }\end{array}$ & $\%$ & $\begin{array}{c}\text { Minimum } \\
\text { number of vessels } \\
(\mathbf{M N V})\end{array}$ & $\%$ \\
\hline plate & 51 & 37.2 & 29 & 38.7 \\
\hline bowl & 52 & 37.9 & 21 & 28 \\
\hline pot & 16 & 11.7 & 12 & 16 \\
\hline mug & 10 & 7.4 & 6 & 8 \\
\hline jug & 7 & 5.1 & 6 & 1.3 \\
\hline lid & 1 & 0.7 & 1 & 100 \\
\hline Total & 137 & 100 & 75 & \\
\hline
\end{tabular}


The open wares prevail in the assemblage - plates (29 specimens, 39\% of all the vessels) and bowls (2I specimens, $28 \%$ of the total). Other items, less frequently noted, belong to the group of closed wares. The mugs and jugs survived in the worst condition; they were found as fragmented bodies, which complicates their stylisticmorphological characteristic. The surfaces of many of the discussed vessels (57\%) are discoloured and damaged, with the covering glaze often chipped (47\%). Hence, the current appearance of these artefacts differs significantly from the original.

In order to analyse the above-described pottery assemblage, I followed the main guidelines of the British Medieval Research Pottery Group for standard procedures related to medieval pottery (cf., MPRG 2016), also used for post-medieval pottery assemblages (e.g., Gaimster 2006). The quantification method was based on the identification of the minimum number of vessels (MNV), which determines the smallest number of vessels that could have produced the sherds found in the ground. The method involves examining all the sherds objectively and placing similar ones, which may have originated from the same vessel, together (Gaimster 2006: 48). All examinations were made by macroscopic method. The slipware was defined by a combination of fabric (colour, texture, surface treatment, and glaze), form, and decorative characteristics (Gaimster 2006: 52), as well as vessel size, method of manufacture, evidence of use, and state of preservation (MPRG 2016: 20-32). I used the glossary of forms and types after the MPRG 1998 (see also Bauer et al., 1986; Orton and Hughes 2013). All the investigated morphological and technological features were noted and entered onto a matching questionnaire (in a database system). The information registered there serves as the foundation for the further conclusions presented below. Selected potsherds were drawn and photographed and prepared for the figures included in the text.

\section{RESULTS - CHARACTERISTIC OF SLIPWARE}

The slipware found at the castle site in Tykocin was of decent quality. The vessels were manufactured from the most common raw materials - ferrous clays - which were adequately prepared. The ceramic mass usually contained sand in the form of glassy grains of quartz (for $60 \%$ of the vessels), characterised by coarse and medium size of grain inclusions (0.5-I mm and 0.25-0.5 mm; cf., Orton and Hughes 2013: 280-282). The ceramic mass of bowls typically contained more coarse-grained inclusions (for $52 \%$ of them), usually due to utilitarian purposes. Single glistering flakes of white mica were also noticed.

The analysed pottery was predominantly (70 vessels, i.e., 93\%) thrown on a potter's wheel. Five slipware vessels were hand-made (i.e., $7 \%$ of the total). The firing was conducted in an oxidising atmosphere and usually well-managed, as evidenced by the homogeneous colour of the core (the section through the wall) in many of the vessels (5I, i.e., $68 \%$ ). However, this process occurred sub-optimally in a significant 
number of pots and bowls (about $40 \%$ for each category), which resulted in bi- or trichromatic cores. Upon firing, the vessels' bodies turned different shades of red - from pink to light brown, with reddish-yellow (5YR6/6-7.5YR6/6 according to Munsell) and yellowish-red (5YR4/6-5/6) being the most common (44 earthenware, i.e., $59 \%$ ), followed by light-red (2.5YR6/6-7/6) or red (2.5YR4/6-5/8), (Munsell 2000).

The walls of these vessels are usually 3 to 7 millimetres thick. The thickness is greater in the parts of the bodies closer to the bases, especially in bowls, and the smallest in the middle parts of bodies in pots and jugs. From the outside, the walls were carefully smoothed, so that no irregularities can be felt. The cores are usually compact and hard (cf., Orton and Hughes 2013: 277). The glaze covering the surfaces of all the vessels is made of lead oxide, colourless, and transparent. It forms a thin layer that got tarnished or chipped in about a half of the specimens, due to post-depositional conditions (Figs 2:9-II; 3:I-2, 6). Apart from its practical purpose, i.e., increasing the impermeability of the vessels, the glaze was also a decoration - it emphasised the colour of the body and its ornamentation and provided the pottery with gloss. The glazing was applied to the already slip-covered and decorated outer walls of pots, jugs, mugs, and lids, as well as the inner walls of plates and bowls. Plates and bowls were also glazed (only partially and not always) on the other, undecorated side, while pots, jugs, and mugs were usually glazed on both sides.

What distinguishes the discussed artefacts is their decoration - colours and patterns. Unfortunately, due to their heavy fragmentation, not much can be said about the arrangement of the ornament or its correlation to the shape of the vessel. In most cases, only small parts of the ornaments are visible. Their specific primary feature is the use of the slip, which is obtained through suspension of fine clay in water (this is present on 60 earthenware, i.e., $80 \%$ ). In $75 \%$ of the discussed vessels, their surfaces had been covered with white slip. Upon firing, such a layer put on clay bodies and under colourless glaze resulted in a bright, beige or yellowish overlay (Figs 2-5). In the case of the remaining $25 \%$ of the earthenware, a brown or green slip was used, thus creating a dark cover, strengthening the natural colour of the raw material (Fig. 6).

Such prepared surfaces were then ornamented. Much less frequently (in Is vessels, i.e., $20 \%$ of the total), the decoration was applied directly on the body. In more than $20 \%$ of the cases (i.e., I7), the state of preservation precluded identification of decorative motifs. The vast majority (62 vessels, i.e., $83 \%$ ) were embellished with colourful painted patterns. Their assortment consists of several schematic groups:

I) floral, the most common ( 27 items, i.e., $36 \%)$ - in the form of stylised leaves, twigs, flowers, buds, and osiers arranged into, as it seems, diverse combinations (Figs 2:I-3, IO-I3; 3:3-4, 9-IO; 6:4);

2) geometrical, less common ( $\mathrm{I} 2$ items, i.e., I6\%) - mostly straight or wavy lines in various arrangements (horizontal, vertical, and diagonal), strips, dots, and circles (Figs 2:5-9; 3:5, 7-8; 6:I-3, 5-8); 


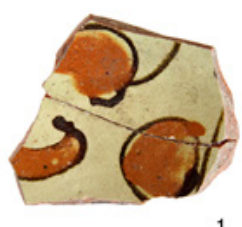

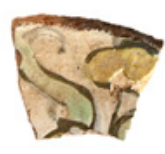

2
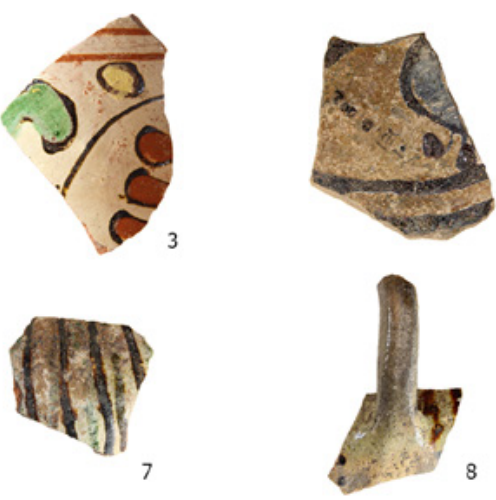
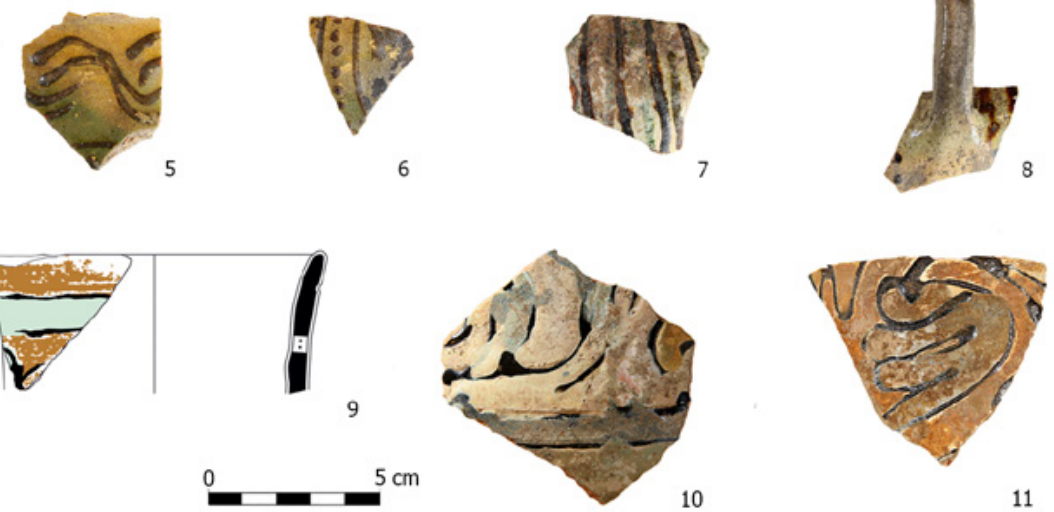

11
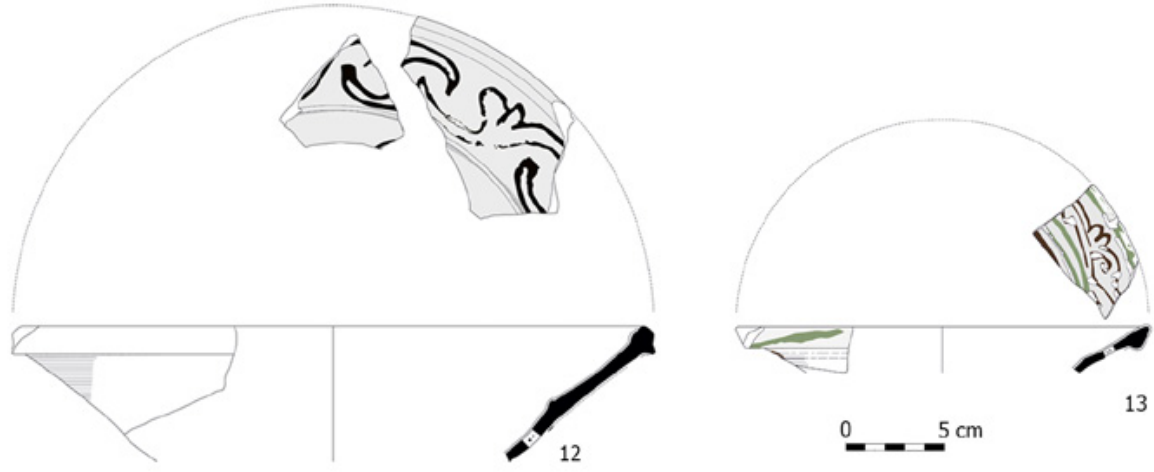

Fig. 2. Slipware from Tykocin Castle with bright slip overlay, brown outline, and precisely painted ornaments, 17th century: 1-3, 10-13 - floral motifs; 4 - zoomorphic (?) motif; 5-9 - geometric motifs. Drawing by M. Wagner, photo and computer graphics by W. Bis.

3) presumably zoomorphic ( $\mathrm{I}$ item) - since the ornament is only partly visible, it remains unclear whether it is a schematic depiction of a sitting bird (its torso and legs) or an element of a different motif (Fig. 2:4); 

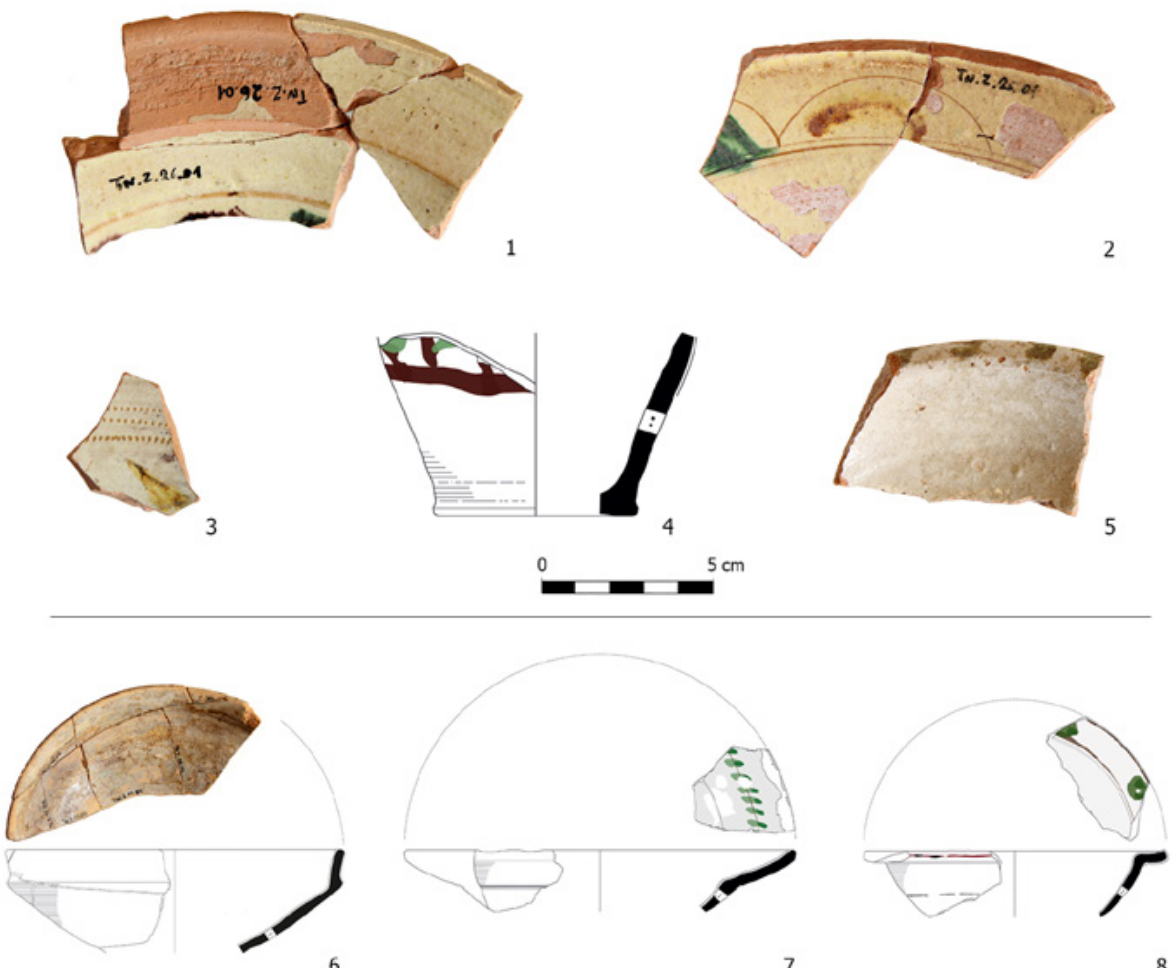

6

7

8

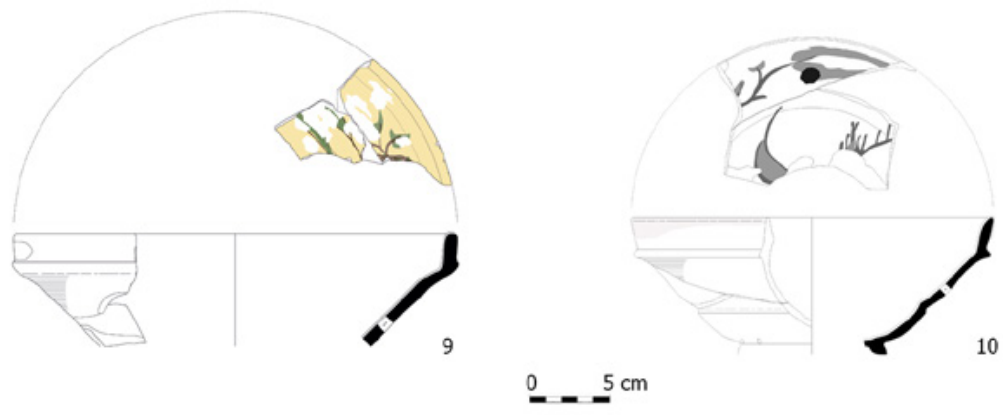

Fig. 3. Slipware from Tykocin Castle with bright slip overlay, simplified painted ornaments, and decorated with other techniques, the second half of the 17th-18th centuries: 1-5, 7-10 - painted ornament; 2 - sgraffito ornament; 3, 6- chattered ornament. Drawing by M. Wagner, photo and computer graphics by W. Bis. 

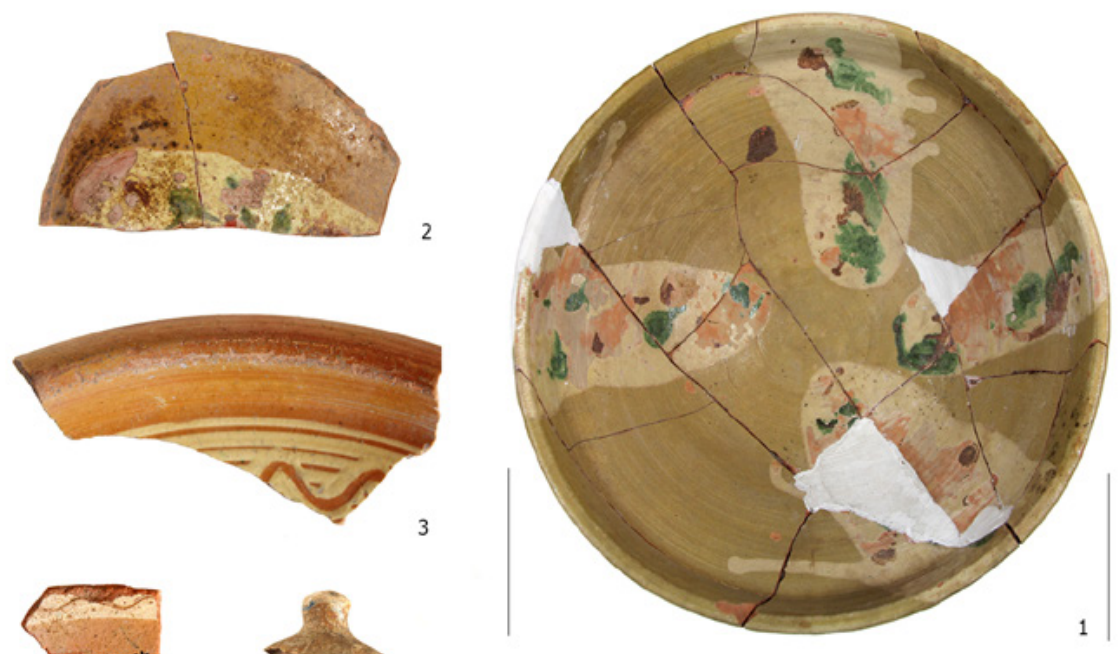

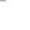
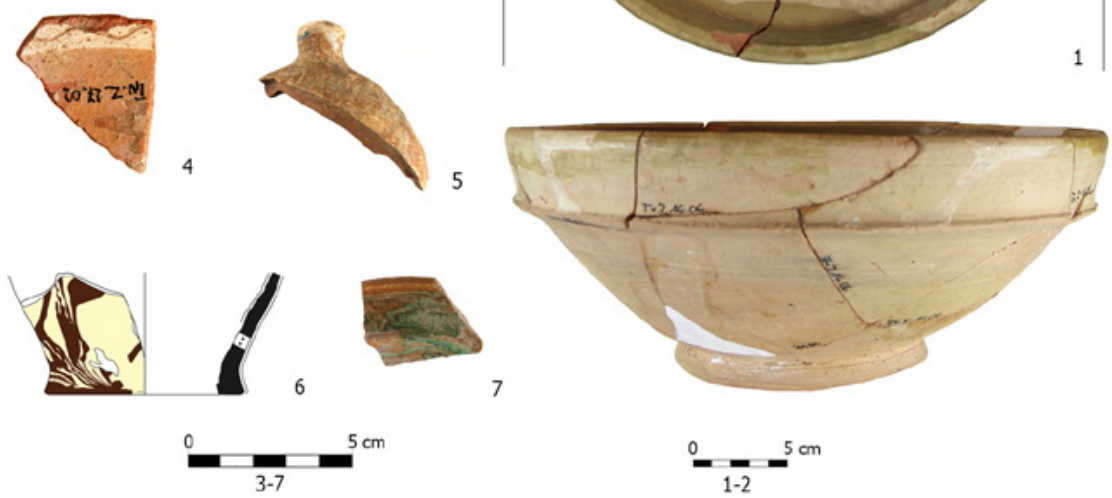

Fig. 4. Slipware from Tykocin Castle with bright (1-4, 6-7) or dark (5) slip overlay, simplified painted ornament, and decorated with other techniques, the second half of the 17 th-18th centuries: $1-2$, 5-spots; 3-4-sgraffito ornament; 6-7 - marbled decoration. Drawing by M. Wagner, photo and computer graphics by W. Bis.

4) colour spots (II items, i.e., I4.7\%) - usually monochrome (green or brown), sometimes bichrome (brown-green), occasionally with streaks scattered irregularly across the surface (Figs 4:I-2; 5);

5) marbled decoration ( 2 items, i.e., $2.6 \%$ ), rare. This ornament was created through marbling - partial mixing of two slip colours on the surface of a vessel (MPRG 1998: chapter 13.2). The marbled decoration is bichrome (white and green or white and brown; Fig. 4:6-7).

The analysed potsherds lacked other original painted motifs, such as human figures, genre scenes, symbols, dates, or sentences. 
$64 \mid$ Magdalena Bis
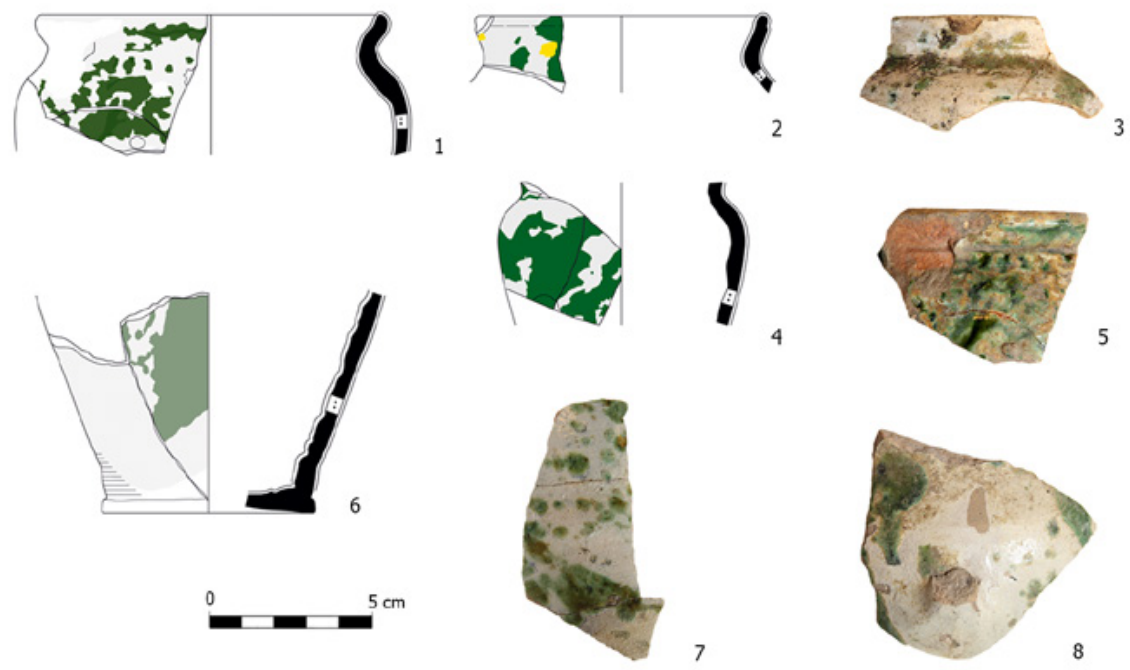

Fig. 5. Slipware from Tykocin Castle with bright slip overlay and simplified painted ornament, the second half of the 17 th-18th centuries: $1-8$ - spots. Drawing by M. Wagner, photo and computer graphics by W. Bis.

The employed colour scheme is limited to several hues: green (a grass-like colour being the most common), brown, white, and yellow, with occasionally occurring turquoise, bluish, or reddish. In $20 \%$ of the vessels, the patterns are outlined in a colour contrasting with the underlayer, which adds to the regularity and sharpness of the motifs. The outline is almost always brown (Is items), with a single white example.

On several vessels, the ornament was applied with different techniques. In three cases $(4 \%)$, it was sgraffito where a part of the slip was removed with a sharp tool to reveal the colour of the underlying layer or that of the clay itself (Orton and Hughes 20I3: 88; MPRG 1998: chapter 12.6) creating a pattern of thin wavy and semi-circular lines (Figs 3:2; 4:3-4). However, five other items (7\%) were decorated with rows (bands) of dots impressed with a chattering tool or a roulette. These dots are dark since their colour matches that of the redware body uncovered below the layer of bright slip (Fig. 3:3, 6). This technique is known as chattering or hemring, in German: Kerbstichdekor, Springfederdekor, Hemrad dekor (see Heege 2019a: 95-96; 2orgb: 84).

Only on three of the analysed vessels was the ornament created with different techniques combined - painted ornament with sgraffito (Fig. 3:2) and painted ornament with chattering (Fig. 3:3). 

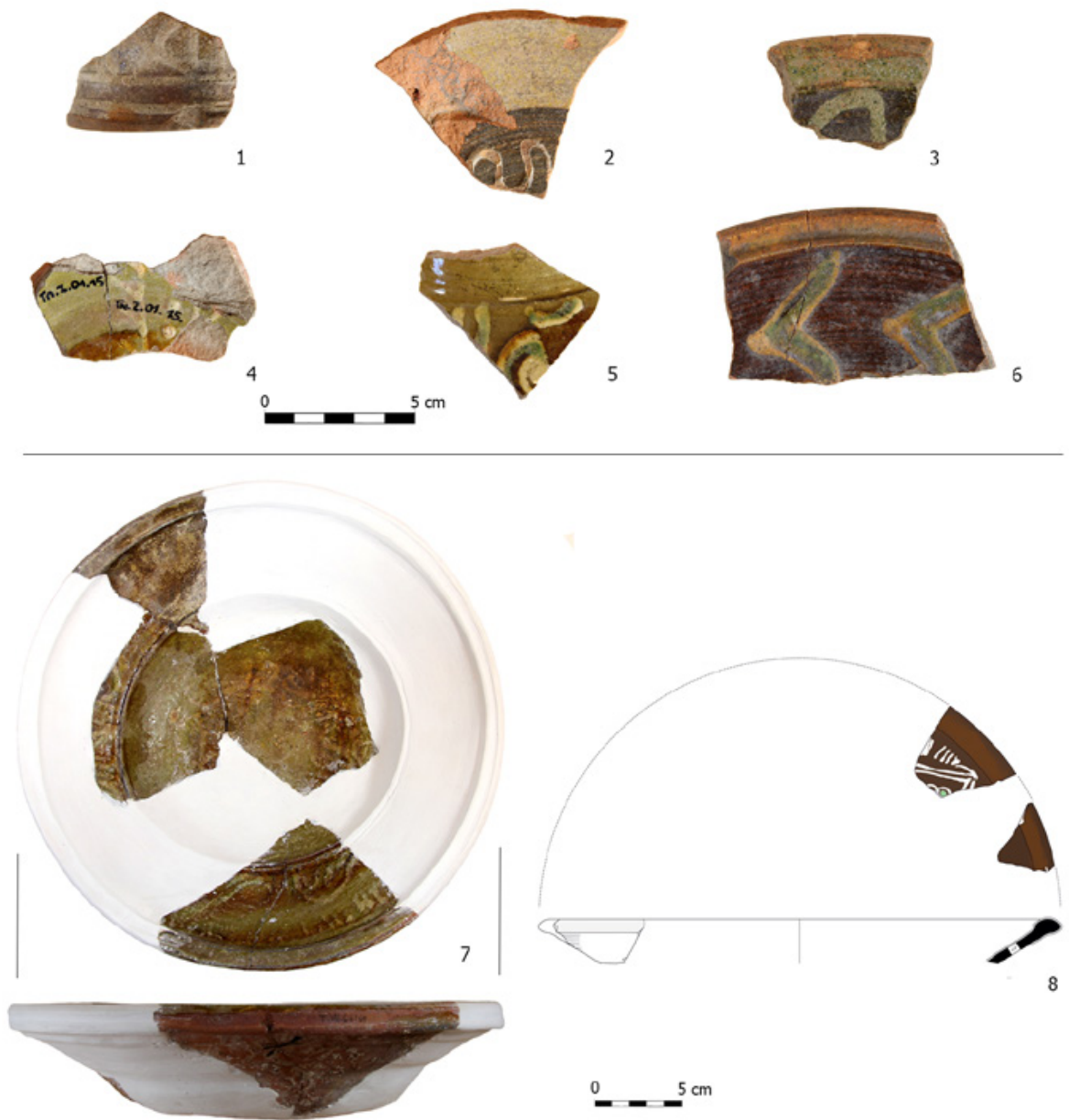

Fig. 6. Slipware from Tykocin Castle with dark slip overlay or without slip cover, with precise and simplified painted ornament, the 17th-18th centuries: 1-3, 5-8 - geometric motifs; 4, 8 - floral motifs. Drawing by M. Wagner, photo and computer graphics by W. Bis.

The most common category in the Tykocin slipware assemblage are plates (see Table I), which represent shallow dishes (e.g., Figs 2:I3; 3:7; 6:7-8). As far as the fragmentation of the vessels allowed, it could be determined that in most cases (6 specimens) their shoulder and body were of similar height, with both parts separated with a gentle cut; alternatively, in rare cases, the shoulder was shorter than the body or the other way round (cf., MPRG 1998: chapter 5.4, forms a-c). Their edges ( $\mathrm{n}=\mathrm{I2}$ ) 
are usually everted from the vessel wall (5) or, less commonly, formed differently inturned (3), clubbed (2), or flat (2; cf., MPRG 1998: chapter II.7.I). Typically, the profile of the rim is collared (7), in some cases thickened (3) or simple (2). The diameters of the edges of the rims range from 20 to $3 \mathrm{I} \mathrm{cm}$. Recurring sizes are 28 (in 4 specimens), 26 , and $30 \mathrm{~cm}$. The bases of the plates $(\mathrm{n}=8)$ are 8 to $\mathrm{I} 2 \mathrm{~cm}$ in diameter, with three specimens measuring $I I \mathrm{~cm}$. It is equally common for them to either have a footring or not; but when they do, the footrings are flat and their surfaces are smoothed. The only reconstructed specimen is $5.5 \mathrm{~cm}$ high. Decorations are applied from the inside, both on the bodies and the rims of the vessels.

The bowls come in diverse sizes, from small through medium to large, although the bigger ones are the most common (e.g., Figs 2:I2; 3:6, 8-IO; 4:I). The prevalence of large bowls is evidenced by their rim diameters ranging from to to $28 \mathrm{~cm}$ and divided into three size categories: IO-II. $4 \mathrm{~cm}$ (3 specimens); I6-2O cm (3); and $2 \mathrm{I}-28 \mathrm{~cm}$ (7). In regard to the profile of their walls, they represent three types: carinated, flared, and rounded bowls (MPRG 1998: chapter 5.I.I-5.I.6). Their preserved and measurable bases $(\mathrm{n}=4)$ range between Io and $\mathrm{I} 2 \mathrm{~cm}$ in diameter. In two cases, it was possible to determine the height of the vessels -8 and $\mathrm{IO} \mathrm{cm}$. In terms of depth, they were probably shallow and medium vessels (MPRG 1998: chapter 5.I). As shown by the investigated sherds $(\mathrm{n}=13)$, the angle of the rim is usually everted (8), sometimes flat (3) or upright (2), whereas the rim forms include: rounded (5), simple (4), thickened (3), and collared (I). The profile of the rim edge is usually rounded (7) or bevelled (6). The shape of the base in profile is concave or flat, with the majority of the bases smoothed from the outside. The ornament is found on the inside of the bodies and the bases or flattened mouths.

Since the plates and bowls are open wares, their inner part forms the largest and most exposed surface suitable for presenting diversely arranged decorative elements. This is attested even by the fragmentarily preserved slipware vessels discussed in this paper. It also reveals this pottery's important decorative purpose.

The pots in the discussed group of vessels are rather small and morphologically close to rounded mugs, i.e., mugs with a rounded body profile below a deep neck and with vertical loop handle(s) (MPRG 1998: chapter 6.3.5); such handles were found on three of them. It may be assumed that these pots were used as individual drinking vessels (Fig. 5:I-4, 6, 8). The diameters of their mouths $(\mathrm{n}=5)$ measure 8 , IO, and $\mathrm{I} 2 \mathrm{~cm}$ (the last measurement obtained from a single specimen), whereas the bases $(n=2)-6$ and $7 \mathrm{~cm}$. The shape of the rim is everted (3 specimens) or inturned (2) in relation to the vessel wall, whereas the profile of the rim edge is rounded or bevelled. Only one base is fitted with a foot. Rod handles are oval in section, measuring I.2 and I.4 $\mathrm{cm}$ in width. The surface of the pots was covered exclusively in white slip, on which was applied decoration composed mostly of monochrome (green) spots, sometimes with streaks, chaotically scattered across rims and bodies. The decoration of these pots shows the most consistency and the least diversity compared to the other vessels. 
Mugs, i.e., basic drinking vessels, are preserved as bodies (5) and a base (I; Figs 2:3; 5:7; 6:I). The base has the diameter of $8 \mathrm{~cm}$ and has a foot. The shape of the bodies suggests that they derive from barrel-shaped, conical, or cylindrical mugs. Presumably, they had different capacities. The majority of the sherds are covered with a bright slip with various patterns (5).

Information about the jugs is limited, due to their fragmentary state of preservation. Mostly parts of bodies ( 5 specimens) were recovered, along with a single fragment of a rim (Fig. 2:9-II). These small sherds reveal little about the shapes of the whole jugs. However, it may be supposed that they were relatively pot-bellied vessels - pear-shaped or shouldered jugs (MPRG 1998: chapter 3.I). The rim, $12 \mathrm{~cm}$ in diameter, is upright (in angle), simple (in form), and internally bevelled (in rim profile). The ornament was applied on a bright or coloured underlayer.

The only lid from the assemblage is a fragmentarily preserved specimen with a shallow domed profile and a central integral knob (Fig. 4:5). The knob is wedge-shaped in elevation (MPRG 1998: chapter 7.I.4c) and measures I.5 cm in diameter. In this case, the ornament, presumably with floral motifs, was applied on a background layer of dark slip.

\section{PROVENANCE, CHRONOLOGY, AND FUNCTION OF SLIPWARE VESSELS}

The slipware used at the castle in Tykocin probably comes from at least several manufacturing centres operating in the post-medieval period. In this context, it is crucial to determine whether they were local products or imports. Answering this question requires indicating those features that would enable identification of particular manufacturing regions and more precise dating of the Tykocin finds.

In terms of technological sophistication, the slipware from the whole discussed period, i.e., from the second half of the I6th century to the second half of the I8th century, is relatively consistent. The basic differences in quality are best visible in ornamentation, despite it being only partially preserved. Two quality standards could be distinguished: carefully and precisely executed, presumably by proficient craftsmen not without a spark of creativity; and more schematic, merely referencing certain stylistic tendencies seen in slipware production, manufactured in a sparing and simplified way by pottery-makers with average skills.

The first group would include most of the specimens with bright background, some vessels with the ornament painted against a dark underlay but outlined with a contour, and specimens with marbled decoration or ornamented with sgraffito and chattering techniques.

These fragments predominantly show features characteristic for the output of the Miechocin workshops from the 17 th century in terms of the precision of the paintings, 
execution of their elements, composition, and colour scheme. The above applies to vessels decorated with different patterns (Figs 2:I-4, 9-I3; 4:6-7; 5; 6:6, 8): floral and geometric on bright background (e.g., Szetela 1969a: 8, Figs I8; II, Fig. 31; I3, Fig. 45; I5, Fig. 57; 30-31, Fig. I23-I25; Szetela 1969b: 58, Fig. 57-59) and dark underlay (Szetela 1969a: II, Fig. 37; 24, Fig. 93; 26, Fig. I02; Szetela 1969b: 92, Fig. 4I), with a bird(?) motif (Szetela 1969a: 22, Fig. 83), and with marbled decoration (Szetela 1969a: 21, Fig. 80; 1969b: 9I, Fig. 38). Analogous products, especially related to the peak of the Miechocin production, are discovered in many places across Poland, e.g., in Elbląg (Marcinkowski 2009; 20I9), Gdańsk (e.g., Oniszczuk 2013b: 95, nr 439-440, 442-443; Dąbal and Szczepanowska 20I8: I8I-I82, Fig. I4:I, 4), Janowiec (Gajewska and Kruppé 20I7: I4I, tabl. 8:I-8), Gdańsk-Wisłoujście (Dąbal 20I5), Płock (Trzeciecki 20I6), Poznań (e.g., Poklewska-Koziełł 20I3; Paterczyk 20I8), Puck (Milewska and Kruppé 20I4; Starski 20I5), Stargard (e.g., Kwiatkowski and Majewski 2016), and Warsaw (Mierosławski 1979; Meyza 1991; 1993; 1996; 2017a; Starski 2013).

The provenance of the specimens decorated with the sgraffito technique has not been determined (Figs 3:2; 4:3-4). The reason for that is their poor state of preservation which prevents identification. It is possible that they are of local production, like similarly decorated finds e.g., from Skaryszewy (unpublished materials, oral communication from Dr Michał Starski).

The vessels with the chattered decoration (Fig. 3:3, 6) probably come from workshops located in Mecklenburg-Vorpommern/western Poland or Sweden (cf., Heege 2019a; 2019b) since specimens from Tykocin find closest parallels in similarly decorated vessels from Myślibórz, dated to the late I6th and early 17 th centuries, and Giessen (Heege 2019a: IOO-IOI, Fig. 8; 20I9b: 89, Abb. Io), as well as those discovered in the Carslburg Castle near Bremerhaven (Heege 2019a: I03, Fig. 15; 2019b: 91, Abb. 17) and Malmö (Heege 2019a: 107-108, Fig. 23). Analogous fragments were obtained, for instance, in Poznań (Poklewska-Koziełł 2013: tabl. 13: 20), Puck (Starski 2015: II7, ryc. II3:6), Siedlęcin (Wojenka 20I6: 235, ryc. 2:9), and Stargard (Kwiatkowski and Majewski 20I6: 182, ryc. 5:60).

The second group, in turn, would include vessels ornamented with colour spots, painted decoration applied directly on the body, and that applied on a dark underlay but without an outline. These also happen to be the youngest finds within the assemblage.

This group of finds may be well represented by two bowls and a plate. The bowls have redware bodies decorated only with strips of white slip covered with irregular green and brown spots (Fig. 4:I-2). The remaining part of their inner surfaces is undecorated and covered with transparent glaze. Their provenance is difficult to determine; perhaps they were imports. They may be dated to the period between the late I7th century and the second half of the i8th century. A similar specimen was found, for example, in Amsterdam, dated to the years 1700-1850, and originating from the Lower Rhineland (Gawronski 2012: 277, no. 995). 
The plate is an unfinished product (Fig. 6:7). A part of its body was covered with brown slip, but the layer melted and blurred. On top of it, a white slip was applied to paint a jagged geometric pattern. The find came from a layer dated to between the I7th century and the second half of the I8th century. Such subpar specimens may have originated from local Podlachian pottery workshops, perhaps operating outside the guilds. I was unable to find any analogies for it in the published works. Potters were active in Tykocin itself and other towns of the region in the post-medieval period, as attested by written records, but there is no information whether slipware was manufactured there at the time (cf., Maroszek 1976).

On the other hand, vessels ornamented with loosely scattered colour (green) spots against an overlay of white slip (Fig. 5) were produced, for example, in the Miechocin workshop in the I8th century (Szetela 1969b: I00, I03, Fig. 69). Such artefacts are known, for instance, from Warsaw (e.g., Meyza I996: 58-59, no. 32; 80-8I, no. 44; 82-83, nos. 48-50), Gdańsk, where they are considered imports from Miechocin (Oniszczuk 20I3 b: 427,438 ), and Prague from the 17 th and I8th centuries. In the last case, they were supposedly products from the Czech centres in Beroun or Levín (Matějková 20I9: I36-137, figs 6-7). The finds from Tykocin Castle are stylistically and chronologically consistent with the aforementioned specimens. They may be dated to the first half of the I7th (?) century and between the mid-i7th century and the second half of the I8th century. However, it is difficult to define where exactly they were manufactured. They are a testimony to pottery trade on, at least, interregional level.

The attribution of the vessels preserved as small fragments with non-characteristic ornamentation remains unknown (e.g., Figs $2: 5-8 ; 3: 4-5,7-8 ; 6: 2-5$ ). Hence, the route which brought these items to Tykocin Castle cannot be reliably reconstructed. Some of the fragments lacking distinguishing features but of otherwise high quality are likely to have been imported from Western Europe.

How did they end up in the castle household? Polish goods were probably bought at local markets and fairs or delivered as a part of the tributes due to the castle. However, there are no written records explicitly confirming such a practice. On the other hand, in the case of the foreign vessels, there are many potential ways of reaching to the fortress. They were purchased (just as many other imported goods) predominantly in the capital (Warsaw) or in the Baltic ports (Gdańsk and Königsberg). Alternatively, they could have been ordered directly from foreign workshops, as evidenced by the I8th-century written accounts about pottery bought for Jan Klemens Branicki (cf., Bis forthcoming).

An equally important question is the way in which slipware was used. Its aesthetic features and the morphology of the vessels would undoubtedly make it a suitable table ware for serving dishes, eating, and drinking. For the same reason, they could have been used as interior decoration, especially that some vessels were prepared specifically for this purpose (e.g., a bowl with a perforated foot for hanging it as a decorative dish). 
70 Magdalena Bis

Their technical parameters combined with the decorative potential suggest that their quality surpassed that of the cheapest and most common kitchen ware - brownware, greyware, and redware. The same is true for the less numerous white ware, of slightly higher quality and also glazed, which would be put on the table and serve secondary purposes in the kitchen and larder. As indicated by the analysis of ceramic finds from Tykocin Castle, the quality and status of the slipware match those of the common vessels of the so-called Pomeranian faïence but are significantly below the quality of other faïences - imported or produced in Polish manufactories - as well as majolica, stoneware, and porcelain - more expensive and rarely recorded in archaeological layers. The slipware was probably used by officials, craftsmen, administrators, etc. - a wide group of consumers of average means - who would have resided in the building.

It is assumed that the demand for this kind of pottery in European countries was a result of the growing requirement for more sophisticated goods, serving as ceramic substitutes for metal- and glassware. This process was fuelled especially by the aspirations of the lower classes to imitate the lifestyle of the aristocracy. Other factors contributing to it may have been an inflow of imported goods and cosmopolitism (cf., Cumberpatch 2003; Gaimster 2006). The local slipware production was a response of the domestic workshops to the new styles and solutions developed by western European workshops and renowned Polish manufactories. As demonstrated by the analysed vessels - probably made in Podlachia region, with mixed results.

\section{CONCLUSIONS}

The slipware obtained from Tykocin Castle, despite the limitations caused by its fragmentary preservation and damaged vessel surfaces, has prompted interesting observations. The assemblage included specimens representing the most popular morphological-stylistic trends and decorative techniques and motifs used in postmedieval pottery from different manufacturing centres. It seems likely that it originated predominantly from Polish workshops, including the renowned Miechocin or the Western-Pomeranian Myślibórz, as well as undetermined foreign production centres. It also contains products of other local workshops, presumably from Podlachia region, which delivered poor imitations of the superior slipware. The majority of the Tykocin finds is dated to the 17 th and 18 th centuries.

They are an example of, and a testimony to, one of the innovative trends in the pottery-making of that period. On the other hand, they also illustrate an important process taking place within post-medieval pottery production - a gradual downturn in the artistic value of the products until it reached the level comparable to the folk pottery of the igth century. 


\section{ACKNOWLEDGMENTS}

I would like to extend my gratitude to Professor Marcin Majewski from the Institute of Archaeology of the University of Szczecin for sharing with me some of the foreign publications. I am also indebted to Rafał Niedźwiadek, MA, from the Archee company, a researcher of Lublin's history, for passing valuable information on the slipware discovered during archaeological excavations conducted in that town.

\section{REFERENCES}

Affelski, J. and Trzeciecki, M. 20I6. Relikty zabudowy bloku śródrynkowego lokacyjnego Ciechanowa (XVI-XVIII w.). Raport II: I7I-I87.

Amato, F., Ercolani, G., Fabbri, B. and Gualtieri, S. 2009. Chemical classification of the slip layers in Italian ceramics of the I5th-I7th century. In K. T. Biró, V. Szilágyi and A. Kreiter (eds), Vessels: inside and outside. Proceedings of the conference EMAC'o7 gth European Meeting on Ancient Ceramics, 223-229. Budapest.

Bartels, M. 1999. Werra-, Weser-aardenwerk en overige Duitse keramiek, circa 1570-1700. In M. Bartels (ed.), Steden in Scherven I. Vondsten uit beerputten in Deventer, Doordrecht, Nijmegen en Tiel (I250-1900). Cities in Scherds I. Finds from cesspits in Deventer, Doordrecht, Nijmegen and Tiel (I250-I900), I7I-I8I. Zwolle.

Bauer, I., Endres, W., Kerkhoff-Hader, B., Koch, R. and Stephan, H.-G. 1986. Leitfaden zur Keramikbeschreibung (Mittelalter - Neuzeit). Terminologie - Typologie - Technologie. München.

Bikić, V. 2017. Ottoman Glazed Pottery Standardization: The Belgrade Fortress Evidence for Production Trends. In S. Bocharov, V. Françoise, and A. Sitdikov (eds), Glazed Pottery in the Mediterranean and the Black Sea Region, Ioth-I8th Centuries. Volume 2, 207-216. Kazan, Kishinev.

Bis, M. (forthcoming). Ceramic and glass vessels from Tykocin castle as the sources for research on the standard of post-medieval consumption - preliminary remarks.

Bis, M. and Bis, W. 2006. Archeologia na zamku w Tykocinie - problemy i postulaty badawcze. In H. Karwowska and A. Andrzejewski (eds), Stan badań archeologicznych na pograniczu polskobiatoruskim od wczesnego średniowiecza po czasy nowożytne, 22I-230. Białystok.

Bis, W. 20I5. Badania archeologiczno-architektoniczne. In M. Bis and W. Bis (eds), Tykocin-zamek nad Narwia (XV-XVIII w.). Badania archeologiczne w latach I96I-1963 i I999-2007, 67-98. Warszawa. Vetera et nova. Opracowanie źródeł archeologicznych z zasobów IAE PAN nowymi metodami badawczymi 4 .

Bis, M. and Bis, W. (eds). 20I5a. Tykocin - zamek nad Narwiq (XV-XVIII w.). Badania archeologiczne w latach I96I-1963 i I999-2007. Warszawa. Vetera et nova. Opracowanie źródeł archeologicznych z zasobów IAE PAN nowymi metodami badawczymi 4.

Bis, M. and Bis, W. 20I5b. Zamek w źródtach historycznych. In M. Bis and W. Bis (eds), Tykocin-zamek nad Narwia (XV-XVIII w.). Badania archeologiczne w latach I96I-1963 i 1999-2007, 23-66. Warszawa, Vetera et nova. Opracowanie źródeł archeologicznych z zasobów IAE PAN nowymi metodami badawczymi 4 . 
Blažková, G. 20I9. Painted Pottery in Bohemia. Slipware of the I6th and the I7th Centuries. In G. Blažková and K. Matějková (eds), Europa Postmediaevalis 20I8. Post-medieval pottery between (its) borders, II5-I27. Gloucester.

Cumberpatch, C. G. 2003. The Transformation of Tradition: the Origins of the Post-medieval Ceramic Tradition in Yorkshire. Assemblage. The Sheffield Graduate Journal of Archaeology 7: no page numbering. https://archaeologydataservice.ac.uk/archives/view/assemblage/html/7/cumberpatch. html (accessed I7.05.202I).

Czopek, S. and Lubelczyk, A. 1993. Ceramika rzeszowska XIV-XVIII wiek. Rzeszów, Zeszyty Naukowe Muzeum Okręgowego w Rzeszowie 3.

Dąbal, J. 2013. Naczynia ceramiczne typu Werra i Wezer w świetle badań archeologicznych przy ul. 3-go Maja 9A w Gdańsku. In E. Fudzińska (ed.), XVIII Sesja Pomorzoznawcza 2. Od późnego średniowiecza do czasów nowożytnych, I23-I35. Malbork.

Dąbal, J. 20I5. Wyroby ceramiczne. In J. Dąbal, K. Krawczyk and T. Widerski (eds), Gdańsk, Twierdza Wistoujście. Badania archeologiczno-architektoniczne w latach 2013-2014. Wistoujście Fortress, Gdańsk. Archaeological and architectural investigations, 2013-2014, 22I-264. Gdańsk.

Dąbal, J. 20I8. Naczynia ceramiczne lokalnej produkcji oraz importowane, użytkowane od XVI do XIX wieku. In A. Pudło, W. Ossowski and E. Trawicka (eds), Jatki mięsne w Gdańsku od XIV do XX wieku, 30I-333. Gdańsk.

Dąbal, J. and Szczepanowska, K. 20I8. W spiżarni, kuchni i na stole - naczynia i sprzęty w domach mieszczańskich. In J. Dąbal (ed.), Domy i ich mieszkańcy w świetle badań archeologiczno-architektonicznych przy ulicy Świętojańskiej 6-7 w Gdañsku, I67-20I. Gdańsk.

Demuth, V. 200I. Weser and Werra Wares in Bergen: An Archaeological Perspective on Aspects of Daily Life in the Town's Early Modern Period. The Bryggen Papers. Supplementary Series 7 (Ships and Commodities): 69-136.

Demuth, V. 20I5. If sherds could tell: imported ceramics from the Hanseatic hinterland in Bergen, Norway. Producers, traders and consumers: who were they, and how were they connected? In G. Hansen, S. P. Ashby and I. Baug (eds), Everyday products in the Middle Ages. Crafts, Consumption and the Individual in Northern Europe c. AD 800-I600, 339-359. Oxbow Books.

Dryja, M. 20I4. Pracownia garncarska z XVI wieku na ul. Loretańskiej iI w Krakowie. In M. Bis and W. Bis (eds), Rzeczy i ludzie. Kultura materialna w późnym średniowieczu i w okresie nowożytnym. Studia dedykowane Marii Dąbrowskiej, I25-I40. Warszawa.

Funke, G. and Leiber, Ch. (eds). 2012. Aus dem Pottland in die Welt. Eine historische Töpferregion zwischen Weser und Leine. Holzminden.

Fryś-Pietraszkowa, E. 1970. Z badań nad majoliką i półmajoliką ludową w Polsce. Polska Sztuka Ludowa 24(2): 67-80.

Gaimster, D. R. M. 1988. Pottery Production in the Lower Rhineland: the Duisburg Sequence ca. 1400I80o. In D. R. M. Gaimster, M. Redknap and H.-H. Wegner (eds), Zur Keramik des Mittelalters und der beginnenden Neuzeit im Rheinland. Medieval and later pottery from the Rhineland and its markets, I5I-I7I. Oxford, British Archaeological Reports International Series 440.

Gaimster, D. I99I. Frühe dekorierte Irdenware Norddeutschlands, Nordfrankreichs, Nordhollands Versucheines Vergleichs. In V. Burhenne, D. R. M. Gaimster, H.-G. Stephan and L. Schilling (eds), Frühe dekorierte Irdenware. Mahlhorndekor und Kammstrichverzierung vom Niederrhein und aus dem Köln-Frechener Raum, 6I-68. Köln, Bonn.

Gaimster, D. R. M. 2006. The Historical Archaeology of Pottery Supply and Demand in the Lower Rhineland, $A D$ I400-I800. Oxford, British Archaeological Reports International Series I5I8. 
Gaimster, D. 2009. An Embarrassment of Riches? Post-Medieval Archaeology in Northern and Central Europe. In T. Majewski and D. Gaimster (eds), International Handbook of Historical Archaeology, 525-548. New York.

Gajewska, M. and Kruppé, J. 20I7. Nowożytne naczynia ceramiczne z wykopalisk w Janowcu nad Wisłą. In J. Kruppé and M. Dąbrowska (eds), Janowiec nad Wistą. Źródta archeologiczne do dziejów miasta (XVI-XVII w.), I08-I4I. Warszawa, Vetera et nova. Opracowanie źródeł archeologicznych z zasobów IAE PAN nowymi metodami badawczymi 6 .

Gajić-Kvaščeva, M., Bikić, V., Wright, V. J., Radosavljević Evans, I. and Damjanović-Vasilić L. 2018. Archaeometric Study of 17 th/18th Century Painted Pottery from the Belgrade Fortress. Journal of Cultural Heritage 32: 9-2I, https://doi.org/I0.I0I6/j.culher.2018.0I.or8 (accessed 09.05.202I).

Garas, M. and Karwowska, H. 2oI3. Naczynia ceramiczne. In H. Karwowska and A. Andrzejewski (eds), Zatożenie rezydencjonalne Sapiehów w Dubnie, 223-256. Białystok.

Garas, M. and Trzciński, Ł. 2oıo. Badania archeologiczne na dziedzińcu Kolegium Jezuickiego w Chojnicach. Zeszyty Chojnickie 25: II-44.

Gawronski, J. (ed.). 2012. Amsterdam Ceramics. A city's history and an archaeological ceramics catalogue II75-20II. Amsterdam.

Giorgio, M. 2019. The Production and Export of Pisan Pottery in the 16th and 17th Centuries. In G. Blažková and K. Matějková (eds), Europa Postmediaevalis 20I8. Post-medieval pottery between (its) borders, I3-23. Gloucester.

Handerek, A. 2006. Ceramika miechocińska. Tarnobrzeg.

Heege, A. 2019a. Springfederdekor - Chattering - Décor guilloché - Hemrad dekor. The History and Development of a Decorative Technique Found on I7th- to I9th-Century Earthenware Ceramics from Scandinavia, Poland, Germany, Switzerland, Austria and Lichtenstein. In G. Blažková and K. Matějková (eds), Europa Postmediaevalis 20I8. Post-medieval pottery between (its) borders, 95-II3. Gloucester.

Heege, A. 20I9b. Springfederdekor - Zur Entstehung einer speziellen Dekortechnik im deutschen Sprachraum. In H.-G. Stephan (ed.), Keramik in Norddeutschland. Beiträge des 48. Internationalen Symposiums für Keramikforschung vom I4. bis 16. September 2015 in Mölln, 84-99. Langenweissbach.

Johansson, M. 2007. Redware vessels in Stockholm. In K. Majantie (ed.), Pots and Princes. Ceramic vessels and stove tiles from 1400-1700, 52-54. Turku, Archaeologia Medii Aevi Finlandiae I2.

Kałagate, S. and Kościukiewicz, M. 2004. Nowożytny ośrodek produkcji półmajoliki w Myśliborzu. In S. Grobica, A. Janiszewska and S. Górka (eds), Odra - przeszkoda czy pomost w ekspansji kulturowej? II Polsko-Niemieckie Spotkania Archeologiczne, Dychów, 29 kwietnia-I maja 2004 r., 383-400. Zielona Góra, Świdnica, Biblioteka Archeologii Środkowego Nadodrza 2.

Kotula, F. 1953. Rzeszowska majolika ludowa. Polska Sztuka Ludowa 4-5: 303-319.

Kotula, F. 1956. Materiaty do dziejów garncarstwa z terenu województwa rzeszowskiego. Rzeszów.

Kröll, K. 20I2. Die frühneuzeitliche Gefäßkeramik der Lüneburger Töpferei „Auf der Altstadt 29”. Rahden/ Westf, Archäologie und Bauforschung in Lüneburg 8.

Kruppé, J. and Milewska, M. 20I4. Dzieje zamku w Pucku. Warszawa.

Kwiatkowski, K. and Majewski, M. 20I6. Wyroby ceramiczne okresu nowożytnego. In M. Majewski (ed.), Archeologia Stargardu 2(2). Badania na obszarze dawnego kościota augustianów, 153-221. Stargard.

Lechowicz, Z. 2012. Zamek w Radomiu. Archeologia i architektura. Badania i interpretacje. Radom.

Linaa, J. 2020. Pottery in Elsinore and Aalborg. In J. Linaa (ed.), Urban Diaspora. The Rise and Fall of Diaspora Communities in Early Modern Denmark and Sweden. Archaeology - History - Science, 331-375. Moesgaard. 
$74 \mid$ Magdalena Bis

Lis, A. 20I7. Zasób źródeł archeologicznych dla studiów nad garncarstwem nowożytnym na Mazowszu. Kwartalnik Historii Kultury Materialnej 65(3): 343-352.

Łaszkiewicz, T. 1993. Renesansowa garncarnia (kaflarnia) na Wzgórzu św. Wojciecha w Poznaniu. In C. Strzyżewski (ed.), Kafle gotyckie i renesansowe na ziemiach polskich: 44-45. Gniezno.

Mackiewicz, M. 20I2. Nowożytna ceramika artystyczna z badań archeologicznych przy kościele św. Piotra i Pawła na Ostrowie Tumskim we Wrocławiu. In A. Pankiewicz (ed.), Nowożytny cmentarz przy kościele św. Piotra i Pawta na Ostrowie Tumskim we Wroctawiu (lata I621-1670), I29-I60. Wrocław. Wratislavia Antiqua. Studia z Dziejów Wrocławia 17.

Majewski, M. 2oIo. Wstępne wyniki interwencyjnych badań archeologicznych przy ul. Ratuszowej w Reczu, pow. choszczeński. Zachodniopomorskie Wiadomości Konserwatorskie 4: I09-I2O.

Majewski, M. 20I6. Recz - miasto na dawnym pograniczu pomorsko-nowomarchijskim. Dotychczasowe wyniki badań archeologicznych. In G. Nawrolska, H. Paner, J. Piekalski and E. Trawicka (eds), Archeologia miast Pomorza w kontekście ziem polskich. Studia dedykowane pamięci Tadeusza Nawrolskiego, 77-90. Gdańsk.

Majewski, M. 20I7. Wyroby ceramiczne okresu nowożytnego. In M. Majewski and K. Stań (eds), Archeologia Stargardu 3. Badania na Rynku Staromiejskim: 95-100. Stargard.

Majewski, M. 2019. Produktion und Distribution von Keramik im Grenzgebiet von Pommern und Neumark im späten I6. Jahrhundert. In M. Schmauder and M. Roehmer (eds), Keramik als Handelsgut. Produktion - Distribution - Konsumption, 205-216. Bonn.

Majewski, M. and Wojciechowska, I. 2019. Ceramika. In M. Majewski (ed.), Archeologia Stargardu 4. Wojna trzydziestoletnia. Pożar miasta $w$ dniu 7 października I635 r., 73-137. Poznań-Stargard.

Marcinkowski, M. 2009. Naczynia angobowane z Miechocina odkryte na Starym Mieście w Elblągu. Elblaskie Studia Muzealne I: I4I-I57.

Marcinkowski, M. 20II. Fajans pomorski ze Starego Miasta w Elblagu. Elbląg.

Marcinkowski, M. 2019. Ceramika nowożytna. In A. B. Kowalska (ed.), Civitas et urbs. Szczecin od średniowiecza do wspótczesności. Kwartat I I, 9I-IO4. Szczecin.

Maroszek, J. 1976. Rzemiosło w miastach podlaskich w XVI-XVIII w. In M. Kwapień, J. Maroszek and A. Wyrobisz, Studia nad produkcja rzemieślniczq w Polsce (XIV-XVIII w.), 88-195. Wrocław. Studia i Materiały z Historii Kultury Materialnej 5r.

Matějková, K. 2019. Bohemian Slipware from the Second Half of the I7th Century until the End of the I8th Century - a Lost Tradition? In G. Blažková and K. Matějková (eds), Europa Postmediaevalis 20I8. Post-medieval pottery between (its) borders, I29-I40. Gloucester.

Meyza, K. 1991. Pseudomajolika znaleziona na terenie Starego Miasta i Zamku Królewskiego. Kronika Zamkowa I(23): II8-I22.

Meyza, K. 1993. Barokowa ceramika. Spotkania z Zabytkami 3: 38-39.

Meyza, K. 1996. Ceramika zdobiona XVI-XVII w. In W. Pela (ed.), Źródta archeologiczne do dziejów Zamku Królewskiego oraz Starej i Nowej Warszawy 2. Warszawa. Materiały do wystawy „Rzeczy codzienne z wykopalisk zamkowych i staromiejskich".

Meyza, K. 1997. 17th century marbled pottery from Warsaw and its origin. In A. Buko and W. Pela (eds), Imported and Locally Produced Pottery: Methods of Identification and Analysis, I25-138. Warszawa.

Meyza, K. 20I7a. Ceramika zdobiona podszkliwnie. In Z. Polak and K. Meyza (eds), Między miastem i dworem. Badania archeologiczne placu Zamkowego w Warszawie w latach 1977-1983. Część 2, 7-23. Warszawa. Archeologia Dawnej Warszawy 4(2). 
Meyza, K. 20I7b. Nowożytny warsztat garncarski ze Starej Warszawy. Nowe ustalenia. Kwartalnik Historii Kultury Materialnej 65(2): 189-196.

Meyza, K. 2019. Ceramika naczyniowa z badań archeologicznych na Placu Krasińskich w Warszawie. In W. Borkowski (ed.), Badania archeologiczne na Placu Krasińskich w Warszawie, 69-90. Warszawa. Warszawskie Materiały Archeologiczne I5.

Miazga, A., Sankiewicz, P. and Sikorski, A. 20I2. Ceramika naczyniowa z badań wykopaliskowych przy murze Lubrańskiego na Ostrowie Tumskim w Poznaniu (ul. Posadzego 5). In H. Kóčka-Krenz (ed.), Poznań we wczesnym średniowieczu 7, 43-103. Poznań.

Mierosławski, M. 1979. Pseudomajolika XVI-XVII w. z Zamku Królewskiego w Warszawie. Rocznik Warszawski 15: 139-I53.

MPRG. 1998. A Guide to the Classification of Medieval Ceramic Forms. London. Medieval Pottery Research Group Occasional Paper I. https://medievalceramics.files.wordpress.com/2019/12/a_guide_to_ the_classification_of_medieval_ceramic_forms.pdf (accessed I8.04.202I).

MPRG. 2016. A Standard for Pottery Studies in Archaeology. Prehistoric Ceramics Research Group, Study Group for Roman Pottery, Medieval Pottery Research Group. Medieval Pottery Research Group Occasional Paper 2. https://medievalpottery.org.uk/wp-content/uploads/2019/ı2/A-Standardfor-Pottery-Studies-in-Archaeology.pdf (accessed I8.04.202I).

Munsell. 2000. Munsell Soil Color Charts. Year 2000 Revised Washable Edition. Grand Rapids.

Niedźwiadek, R. 20I9. Dzieje placu Litewskiego w perspektywie badań archeologicznych. In R. Niedźwiadek (ed.), Krakowskie Przedmieście w 45o-lecie Unii Lubelskiej, 229-270. Lublin.

Niukkanen, M. 2007. The Form and Decoration of Redware Vessels: Functionality and Hidden Symbolic Meanings. In K. Majantie (ed.), Pots and Princes. Ceramic vessels and stove tiles from ${ }^{4400-I 700,}$ 3I-35. Turku. Archaeologia Medii Aevi Finlandiae I2.

Oniszczuk, A. 20I3a. Życie odbite w naczyniu. Konsumpcja luksusowa i codzienna w Gdańsku w XVIIXIX wieku na podstawie naczyń ceramicznych z terenu Centrum Dominikańskiego i kwartatu Dtugi Targ - Powroźnicza. Tom I. Warszawa.

Oniszczuk, A. 2oI3b. Życie odbite w naczyniu. Konsumpcja luksusowa i codzienna w Gdańsku w XVIIXIX wieku na podstawie naczyń ceramicznych z terenu Centrum Dominikańskiego i kwartatu Dtugi Targ - Powroźnicza. Tom II: Katalogi. Warszawa.

Orton, C. and Hughes, M. 2013. Pottery in Archaeology, Second Edition. Cambridge, New York.

Ose, I. 2019. Turaidas pilī atrastie I3.-I9. GS. importa un vietêjie vācu keramikas trauki. 13th-19th Century Imported and Locally Made German Ceramic Vessels Found at Turaida Castle. In I. Stašulāne and A. Legzdiña (eds), Turaidas pils 10.-I9. gadsimta keramikas trauki. Ceramic Vessels at Turaida Castle in the Ioth-19th Centuries, 62-96, III-I36. Rìgā. https://www.turaida-muzejs.lv/wp-content/ keramikas-trauki/index.html (accessed 09.05.2021).

Pankiewicz, A. and Rodak, S. 20I6. Śląska ceramika jako źródło do poznania garncarstwa okresu wczesnonowożytnego. In S. Siemianowska, P. Rzeźnik and K. Chrzan (eds), Ceramika i szkto $w$ archeologii $i$ konserwacji, 33I-356. Wrocław.

Paterczyk, N. 20I8. Ceramika naczyniowa. In P. Pawlak (ed.), Średniowieczny system obronny miasta Poznania. Fragment odcinka pótnocnego. Wyniki badań archeologicznych, 5I-I32. Poznań. Bibliotheca Fontes Archaeologici Posnanienses 20.

Pawlata, L. 20I3. Archeologiczne badania wykopaliskowe na dziedzińcu kuchennym pałacu Branickich w Białymstoku. Podlaskie Zeszyty Archeologiczne 9: I2I-I76. 
Poklewska-Koziełł, M. 2013. Ceramika naczyniowa. In P. Pawlak (ed.), Średniowieczny system obronny miasta Poznania. Odcinek pótnocno-zachodni. Wyniki badań archeologicznych, 97-16I. Poznań. Bibliotheca Fontes Archaeologici Posnanienses 15.

Pytlak, M. 20I3. Naczynia ceramiczne z terenu kościoła dawnego opactwa cysterskiego w Mironicach. Archeologia Środkowego Nadodrza I0: 59-79.

Rodak, S. 20I7. Ceramika nowożytna z badań na Starym Mieście w Brzegu. Kwartalnik Historii Kultury Materialnej 65(2): 149-167.

Russow, E. 2006. Importkeraamika Lääne-Eestilinnades 13.-17. Sajandil. Imported pottery in West Estonian towns between I3th and I7th centuries. Tallin.

Russow, E. and Haak, A. 20I8. An outline of pottery production and consumption in medieval and early modern Estonia. In E. Russow and A. Haak (eds), 2nd Meeting of Baltic and North Atlantic Pottery Research Group Tallinn, I2th and 13th April 20I8. Programme - Abstracts - Outlines, 5I-75. Tallin.

Schäfer, H. 2007. Redware vessels in medieval and early modern Mecklenburg-Vorpommern. In K. Majantie (ed.), Pots and Princes. Ceramic vessels and stove tiles from I400-I700, 85-87. Turku. Archaeologia Medii Aevi Finlandiae I2.

Starski, M. 20I3. Nowożytne naczynia ceramiczne z badań północnej pierzei placu Teatralnego w Warszawie. In W. Pela (ed.), Badania archeologiczno-architektoniczne pótnocnej pierzei placu Teatralnego $w$ Warszawie w latach 1995-1997, 134-185. Warszawa. Archeologia dawnej Warszawy 3.

Starski, M. 20I5. Rynek miasta lokacyjnego w Pucku w świetle badań archeologicznych. Warszawa.

Stephan, H.-G. 1987. Die bemalte Irdenware der Renaissance in Mitteleuropa. Ausstrablungen und Verbindungen der Produktionszentren im gesamteuropäischen Rahmen. Renaissance Decorated Pottery in Central Europe. Influences and Links of production centers throughout Europe. München.

Stephan, H.-G. 199I. Neue Forschungen zur Werraware der Renaissance. Unter Besonderer Berücksichtigung der Verbindungen zu den Niederlanden und der frühen Malhornware des Rheinlandes. In V. Burhenne, D. R. M. Gaimster, H.-G. Stephan and L. Schilling (eds), Frühe dekorierte Irdenware. Mahlhorndekor und Kammstrichverzierung vom Niederrhein und aus dem Köln-Frechener Raum, 69-85. Köln, Bonn.

Szarek-Waszkowska, E. 1967. Badania nowożytnej osady garncarskiej w Miechocinie pow. Tarnobrzeg. Materiaty i Sprawozdania Rzeszowskiego Ośrodka Archeologicznego za rok 1966: 256-262.

Szetela, T. 1969a. Ceramika z Miechocina. Polska Sztuka Ludowa 23(I): 3-42.

Szetela, T. 1969b. Ceramika z Miechocina (dokończenie). Polska Sztuka Ludowa 23(2): 75-108.

Szetela-Zauchowa, T. 1994. Miechocin. Nowożytny ośrodek garncarski. In A. Gruszczyńska and A. Targońska (eds), Garncarstwo i kaflarstwo na ziemiach polskich od późnego średniowiecza do czasów wspótczesnych. Materiaty z konferencji-Rzeszów, 2I-23.IX.1993, 45-72. Rzeszów.

Szwed, R. 2004. Wczesnonowożytna ceramika naczyniowa z ulicy św. Antoniego we Wrocławiu. In J. Piekalski and K. Wachowski (eds), Wroctaw na przetomie średniowiecza i czasów nowożytnych. Materialne przejawy życia codziennego, 33I-38I. Wrocław. Wratislavia Antiqua. Studia z Dziejów Wrocławia 6.

Szymczyk, M. 20II. Nowożytny ośrodek garncarski w Myśliborzu (Soldin). In J. Kochanowska (ed.), Trzebiatów - spotkania pomorskie 20II, I8I-I20. Trzebiatów.

Supryn, M. 1975. Półmajolikowa ceramika z Jarosławia. Wiadomości Archeologiczne 40(2): 239-264.

Świechowska, A. and Dukwicz, R. 1955. Warsztat garncarski z końca XVII w. In O. Puciata, H. Szwankowska, E. Szwankowski and S. Żaryn (eds), Szkice staromiejskie, I5I-I60. Warszawa. 
Trąbska, J., Kocańda, P. and Trybalska, B. 2019. Modern Semi-Majolica and Glazed Ceramics from Rzeszów - Research on the Findings from the Archaeological Sites on 3 Maja Street. Analecta Archaeologica Ressoviensia I4: 109-136. DOI: 10.15584/anarres.2019.14.9.

Trzeciecki, M. 2016. Ceramika Ptocka między XI a XIX wiekiem. Studium archeologiczne. Warszawa.

Trzeciecki, M. 20I7. Naczynia gliniane z XVII-XVIII wieku, z badań zespołu podworskiego w Niegowie pod Wyszkowem. Przyczynek do poziomu życia szlacheckiej prowincji. Kwartalnik Historii Kultury Materialnej 65(2): 169-187.

Witte, F. 20I4. Bemalte Teller im Garten. Eine Töpferei der Renaissance in Husum. Husum.

Witte, F. 20I6. Post Medieval Slipware from Northern Germany and Southern Denmark. In M. Ferri, C. Moine and L. Sabbionesi (eds), In \& Around. Ceramiche e comunità. Secondo convegno tematico dell'AIECM3. Faenza, Museo Internazionale delle Ceramiche, I7-I9 aprile 2015, 241-244. Venezia.

Wojenka, M. 20I6. Nowożytne naczynia półmajolikowe. In P. Nocuń (ed.), Wieża książęca w Siedlęcinie $w$ świetle dotychczasowych badań. Podsumowanie na 700-lecie budowy obiektu, 232-240. Siedlęcin, Pękowice, Kraków.

Włoszek, M. 20I7. Naczynia gliniane z badań na dziedzińcu Arsenału Warszawskiego. In W. Borkowski (ed.), Badania archeologiczne dziedzińca Arsenatu Królewskiego oraz zespotu Kamienicy Raczyńskich $w$ Warszawie I, I03-I07. Warszawa, Warszawskie Materiały Archeologiczne I4.

Wołyńska, M. 2020. Wybrane naczynia gliniane z wykopalisk na Targu Siennym w Gdańsku. In S. Siemianowska, P. Rzeźnik and K. Chrzan (eds), Ceramika i szkto w badaniach interdyscyplinarnych, 77-I22. Wrocław.

Wyrwińska, E. and Wyrwiński, J. 2005. XVII wieczne piece garncarskie ze Śmigla. Fontes Archaeologici Posnanienses 4I: 299-308.

Zamelska-Monczak, K. 2020. Średniowieczna i nowożytna ceramika naczyniowa z badań ratowniczych przeprowadzonych w Ujściu w 2008 roku. Materiaty Zachodniopomorskie. Nowa Seria 16: 135-190. 